Article

\title{
Quantification of Improvement in Environmental Quality for Old Residential Buildings Using Life Cycle Assessment
}

\author{
Jozef Mitterpach $^{1}$, Emília Hroncová ${ }^{2, *}$, Juraj Ladomerský ${ }^{2}$ and Jozef Štefko ${ }^{3}$ \\ 1 Department of Environmental Engineering, Faculty of Ecology and Environmental Sciences, \\ Technical University in Zvolen, T.G. Masaryka 24, 96053 Zvolen, Slovakia; jozef.mitterpach@gmail.com \\ 2 Department of Environmental Management, Faculty of Natural Sciences, Matej Bel University, \\ Tajovského 40, 97401 Banská Bystrica, Slovakia; juraj.ladomersky@umb.sk \\ 3 Department of Wooden Constructions, Faculty of Wood Sciences and Technology, Technical University in \\ Zvolen, T.G. Masaryka 24, 96053 Zvolen, Slovakia; stefko@tuzvo.sk \\ * Correspondence: emilia.hroncova@umb.sk or emilia.hroncova@gmail.com; Tel.: +421-455-206-417 \\ Academic Editor: Tan Yigitcanlar \\ Received: 22 November 2016; Accepted: 8 December 2016; Published: 11 December 2016
}

\begin{abstract}
In Slovakia, 35\% of buildings are older than 50 years but most newer buildings built before 1990 have greater energy consumption. Some other countries also have similar problems. The growing importance of energy saving in buildings can be, in the case of new and old residential buildings (RB), achieved by lowering thermal energy consumption most often by application of polystyrene insulation on the external walls and roof and the exchange of wood window frames for PVC (polyvinyl chloride) windows. The novelty of the article for Slovakia and some other central European countries consists in using the life cycle assessment (LCA) method for the objective assessment of the environmental benefits of the selected systems of wall insulation, as well as of energy savings in various time intervals of insulation functionality (up to 20 years). LCA software SimaPro (LE Amersfoort, The Netherlands) was used with ReCiPe and IMPACT 2002+ assessment methods to quantify the total environmental impact at selected endpoints and midpoints (IMPACT 2002+) of basic structural materials of an RB and its energy demand-heat consumption (hot water heating, central heating) before the application of insulation and thermal energy saving (TES) after application of insulation to its external walls, roof, and the exchange of windows. The data we obtained confirmed that the environmental impact of the polystyrene insulation of external walls, roof, and exchange of windows of one residential building (RB) in the first year after insulation is higher than the reduction caused by achieving a TES of 39\%. When taking a lifespan of 20 years into consideration, the impact over the life cycle of the building materials is reduced by $25 \%$ (global warming: $-4792 \mathrm{~kg}$ $\mathrm{CO}_{2}$ eq; production of carcinogens: $-2479 \mathrm{~kg} \mathrm{C}_{2} \mathrm{H}_{3} \mathrm{Cl}$ eq; acidification: $-12,045 \mathrm{~kg} \mathrm{SO}$ eq; and aquatic eutrophication: $-257 \mathrm{~kg} \mathrm{PO}_{4} \mathrm{P}$-lim). The verified LCA methodology will be used for comparative analysis of different variants of thermal insulation of buildings, and their functionality in the long term, while taking into account local specifics and the preparation of environmental product declarations.
\end{abstract}

Keywords: LCA; residential building; polystyrene; insulation; energy; environmental impact

\section{Introduction}

The social-economic and environmental indicators of sustainable development are focused on the building industry as a globally-expanding sector with a high level of activity in developed, as well as developing, countries [1]. The topic of sustainable construction, defined in the basic document-Agenda 21—for sustainable construction, represents a large complex of issues with a large 
number of parameters from various areas of the construction industry [2]. Due to a complicated interaction between construction and the environment, the life cycle assessment (LCA) of buildings represents a comprehensive approach to surveying the impact of a building on the environment in all phases of its life cycle [3-5]. The methods of LCA have been used to evaluate the production process of various products for quite a long time. Application of this method in the construction industry has been known for the last 10-13 years [6]. Due to the fact that the LCA method includes a complex and systemic approach to environmental assessment, there is interest in including the LCA method into the construction decision-making process for selection and preference of ecological products, as well as the evaluation and optimization of construction processes [7]. The optimization of a building construction proposal, from the point of view of environmental parameters, represents a large multi-criteria issue $[8,9]$ and it has a significant impact on the total consumption of natural resources and the release of emissions [10]. According to Scheuer et al. [11], it is necessary to consider the consumption of raw materials, construction materials, and energy during the phase of construction and usage. However, transport of construction materials, possibility to recycle and waste handling in other phases of life cycle should be also considered in relation with the fact that buildings consume energy during their whole life cycle. The type of a construction material used may be assessed from many aspects, provided especially by the LCA system, e.g., according to Guardigli et al. [12], wood as a construction material is better than concrete in terms of health, resource usage, as well as general ecological quality. Similarly, Chau et al. [13] state that selection of materials for recycling or reuse in a building and the optimum number of reuses of a particular material considerably influence the impact of buildings on the environment within life cycle assessment. The studies of Pajchrowski et al. [3] and Lewandowska et al. [14], comparing houses made from bricks and wood, confirm that the main source of negative impact on the environment, in the long-term usage phase, is represented by the energy consumption in the residential building (RB) life cycle. According to Sartori and Hestnes [10], the energy demand in buildings during their life cycle are direct (construction, operation, reconstruction, and demolition) and indirect (production of materials required for construction of a building). The comprehensive assessment of a residential building regarding energy consumption and environmental impact requires application of the LCA method to enable quantification of environmental impacts (EI) and identification of the most sustainable solutions and, therefore, lowering energy demand $[15,16]$. Even despite the fact that the LCA and its global scope are defined in a set of international standards, the particular methodology depends on the first step, e.g., setting the goals and scope of analysis; therefore, it is necessary to execute LCA studies of residential buildings and their energy demand during the whole life cycle $[17,18]$. Due to the number of residential buildings and long-term utilization during the year, residential buildings represent an important potential for lowering energy consumption and negative impacts on the environment $[19,20]$.

The majority of residential buildings built in Slovakia (former Czechoslovakia) in 1968-1990 fail to meet current thermal and technical requirements. Additionally, $35 \%$ of residential buildings are more than 50 years old. Unsuitable materials were often used for construction, incorrect projects were used, or even construction technology was not properly used. To eliminate such deficiencies, measures to improve the thermal protection and lower the thermal energy demand of such buildings are used. Such measures include insulation of the external walls and roof using polystyrene and exchange of windows, therefore, achieving thermal energy saving (TES). This contribution, therefore, shows the environmental assessment of external wall and roof insulation of a residential building (RB) by polystyrene and the exchange of windows as energetically efficient measures and prolongation of the residential building life cycle. So far we have not recorded such detailed analyses of improving the thermal protection of the residential buildings in Slovakia and some other Central European countries.

\section{Goal and Scope}

The goal of this LCA study is to determine the environmental impacts of basic construction materials of one residential building and its energy demand-heat consumption (water heating, central 
heating) - before the application of insulation and energy savings generated by insulation of external walls, roof, and the exchange of windows after the application of insulation, using two evaluation methods at selected endpoints, in the usage phase of the residential building in various periods of its life cycle of 20 years. Modelling was performed for periods of one, five, 10, and 20 years for better comparison of different construction materials, insulation materials, and window replacement (considering their function and useful life).

\section{Materials and Methods}

\subsection{Residential Building}

The residential building (Figure 1) was built in accordance with the standardized basic document (type T06B), implemented by a Czechoslovak state-owned enterprise in 1978. Since the type of RB failed to meet the current thermal and technical requirements, it was insulated with polystyrene in 2010. The insulation was applied to external walls using a contact thermal and insulation system with a thickness of $100 \mathrm{~mm}$, insulation and isolation of the roof using an isolation system (polystyrene with a thickness of $60 \mathrm{~mm}+2 \times$ self-adhesive bitumen strips) and by exchanging the wooden windows for the PVC windows.

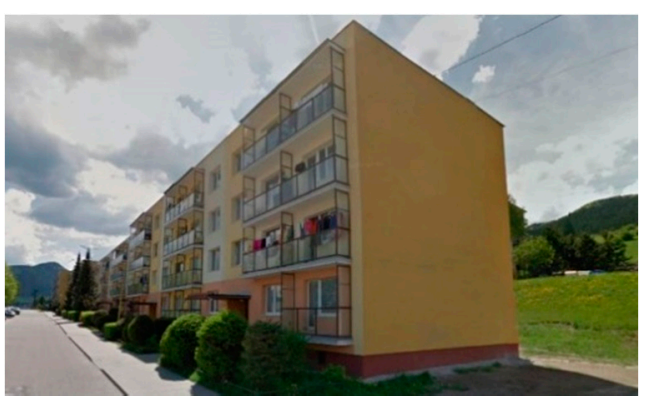

(a)

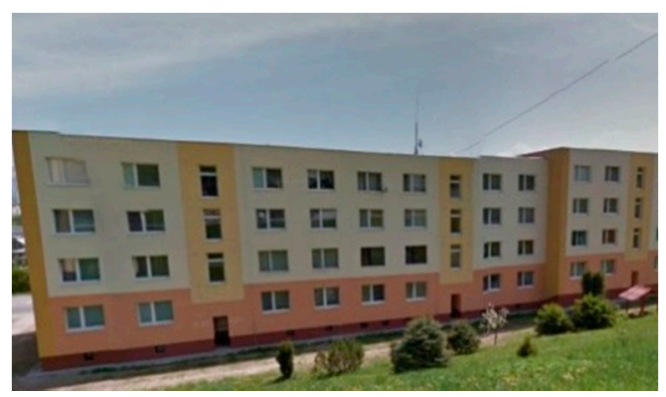

(b)

Figure 1. Residential building after the application of insulation: (a) northeast view; and (b) west view.

The basic data of the $1 \mathrm{RB}$ is included in Table 1 and material flows for the RB are included into the LCA in Table 2. The results are calculated for a functional unit of $1 \mathrm{RB}$. The functional unit of $1 \mathrm{RB}$ was selected as the most suitable option for further comparison. If needed for comparison, the results can be calculated for various surfaces (floor and heating surfaces etc.) listed in Table 1.

Table 1. The basic data of RB.

\begin{tabular}{cc}
\hline Building Technology & Prefab Reinforced Concrete Panels \\
\hline Final building approval & $8 / 1978$ \\
Storey/Entrances/Apartments & $5 / 9 / 99$ \\
Length $\times$ width $\times$ height & $183.00 \mathrm{~m} \times 12.60 \mathrm{~m} \times 15.00 \mathrm{~m}$ \\
Building area & $2305.80 \mathrm{~m}^{2}$ \\
Floor space of apartments & $6777.52 \mathrm{~m}^{2}$ \\
Heated area of apartments & $6362.61 \mathrm{~m}^{2}$ \\
Area of insulation & $7448.00 \mathrm{~m}^{2}$ \\
External walls & $150 \mathrm{~mm}$ reinforced concrete panels $+300 \mathrm{~mm}$ slag pumice concrete \\
Roof & double skin flat with ventilation air gap \\
Windows & $726.0 \mathrm{~m}^{2}$, double wing \\
\hline
\end{tabular}


Table 2. Material inputs of RB before and after application of polystyrene insulation and exchange of windows.

\begin{tabular}{|c|c|c|c|c|}
\hline External Walls & $\mathrm{mm}$ & $\mathrm{m}^{2}$ & $\mathrm{~m}^{3}$ & kg \\
\hline Facade silicate plaster & 1.5 & 3596 & 5.4 & $11,328.2$ \\
\hline Slag pumice concrete & 300 & 4100 & 1200 & $1,740,000.1$ \\
\hline Reinforced concrete panel & 150 & 3925 & 588.8 & $1,236,375.0$ \\
\hline Sealant & - & 230 & 23.0 & $34,500.1$ \\
\hline External walls, insulation & $\mathrm{mm}$ & $\mathrm{m}^{2}$ & $\mathrm{~m}^{3}$ & $\mathrm{~kg}$ \\
\hline Facade silicate plaster & 1.5 & 3503 & 5.3 & 9458.9 \\
\hline Polystyrene & 100 & 3088 & 308.8 & 5558.7 \\
\hline Socle silicate plaster & 1.5 & 327.9 & 0.5 & 885.3 \\
\hline Polystyrene XPS, socle & 50 & 327.9 & 16.4 & 295.1 \\
\hline Base for plaster & 2 & 70.6 & 0.1 & 225.8 \\
\hline Outer core plaster & 10 & 70.6 & 0.7 & 846.7 \\
\hline Window insulation lining & 30 & 415.1 & 12.5 & 224.2 \\
\hline Aluminium socle profile & $328.0 *$ & - & - & - \\
\hline Aluminium window profile & $2747.0 *$ & - & - & - \\
\hline Plastic ventilation grille & $198.0 *$ & - & - & 55.4 \\
\hline Coatings & - & 7.8 & 0 & 53.3 \\
\hline Roof, original construction & $\mathrm{mm}$ & $\mathrm{m}^{2}$ & $\mathrm{~m}^{3}$ & $\mathrm{~kg}$ \\
\hline Bitumen layer & 3.5 & 2289 & 8.0 & 9893.3 \\
\hline Asphalt layer & 5.3 & 2289 & 12.1 & $15,527.2$ \\
\hline Cement screed & 20 & 2059 & 41.2 & $84,410.8$ \\
\hline Gas silicate boards & 150 & 2113 & 316.9 & 174,306 \\
\hline Roof, insulation & $\mathrm{mm}$ & $\mathrm{m}^{2}$ & $\mathrm{~m}^{3}$ & $\mathrm{~kg}$ \\
\hline Asphalt layer & 2.7 & 2280 & 6.2 & 8616.6 \\
\hline Asphalt layer & 4.2 & 2747 & 11.5 & $16,149.8$ \\
\hline Polystyrene & 60 & 1995 & 119.7 & 3590.2 \\
\hline Windows & $\mathrm{W} / \mathrm{m}^{2} \cdot \mathrm{K}$ & $\mathrm{m}^{2}$ & ks & $\mathrm{kg}$ \\
\hline Wooden windows & 1.5 & 725.8 & - & - \\
\hline Plastic window & 1.6 & 725.8 & - & - \\
\hline Energy & & & & GJ/year \\
\hline Before insulation & & & & 2121.73 \\
\hline After insulation & & & & 1298.58 \\
\hline
\end{tabular}

${ }^{*}$ meter $(\mathrm{m})$.

The load-bearing system of the elongated-shaped RB is made using vertical, load-bearing, reinforced concrete walls with a structural module of $3600 \mathrm{~mm}$. The construction depth of floors is $2800 \mathrm{~mm}$. The faced walls, as part of the vertical load-bearing system, are double-layered, the load-bearing element is a reinforced concrete panel (150 mm thickness), and sheathing of $300 \mathrm{~mm}$ is a holy-stone and concrete panel. Between the panels there is an air gap of $5 \mathrm{~mm}$. There are four above-ground levels and one under-ground level serving for amenities in the elongated-shaped RB. Some flats are equipped with balconies or semi-flush-mounted loggias (Figure 1). Regarding the external walls of the RB before the application of insulation, the greatest deficiencies and faults were in the place of joints and gaps of external wall panels. In the RB, flexible sealants were used to seal the joints and gaps, however, during the course of usage, they lost their flexibility and, therefore, they ceased to fulfil their original function. To reduce heat and sound bridges, flexible inserts were inserted into the joints. The deficiencies in joints of the RB external walls and insufficient thermal and technical properties were eliminated by application of comprehensive insulation of outside walls with overlapping corner insulation in such way as to eliminate the heat bridge in the corners of residential rooms, which were the most exposed from the point of view of surface temperature and steam condensation.

The roof is a single-sheathed structure with thermal insulation using by porous concrete with thickness of $150 \mathrm{~mm}$. The top sheathing is made of porous concrete roof panels with thickness of $240 \mathrm{~mm}$; however, they are excluded from the thermal-insulation sheathing by a ventilation air 
gap (not included into the inventory analysis). They serve as a base for the asphalt and bitumen hydro-isolation layer with the gradient of $3 \%$ into the inner spout pipes. The original flat roof on the panel RB was not suitable due to its low thermal resistance of $\mathrm{R}=1.34 \mathrm{~m}^{2} \cdot \mathrm{K} / \mathrm{W}$ and boundary conductance of $\mathrm{U}=0.67 \mathrm{~W} / \mathrm{m}^{2} \cdot \mathrm{K}$, while the steam condensation was occurring, too. By insulating the roof, the thermal resistance was adjusted to $\mathrm{R}=3.42 \mathrm{~m}^{2} \cdot \mathrm{K} / \mathrm{W}$ and boundary conductance to $\mathrm{U}=0.28 \mathrm{~W} / \mathrm{m}^{2} \cdot \mathrm{K}$, i.e., satisfactory values.

The original windows of the RB were wooden windows with satisfactory thermal resistance $\left(\mathrm{U}=1.5 \mathrm{~W} / \mathrm{m}^{2} \cdot \mathrm{K}\right)$, however, due to the end of their life cycle and functionality, they were exchanged for the PVC windows $\left(\mathrm{U}=1.6 \mathrm{~W} / \mathrm{m}^{2} \cdot \mathrm{K}\right)$.

The heat demand on the RB in the phase of usage is necessary for the preparation of hot water as well as for central heating. The heating system of the RB is a hot-water, double-pipe system. For environmental assessment, an average annual thermal energy consumption value of 823.149 GJ/year was used (Figure 2a,b).

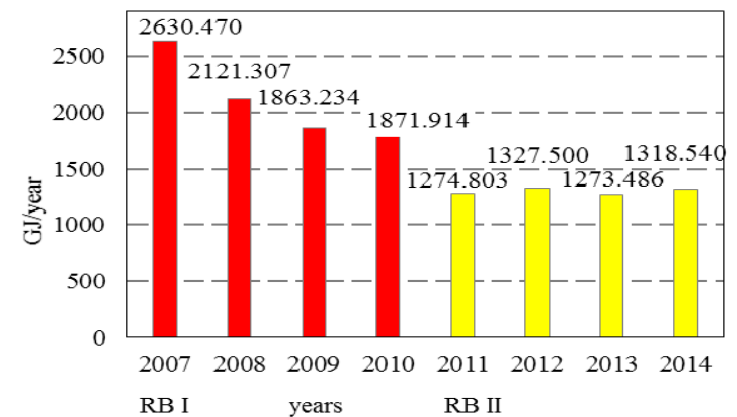

(a)

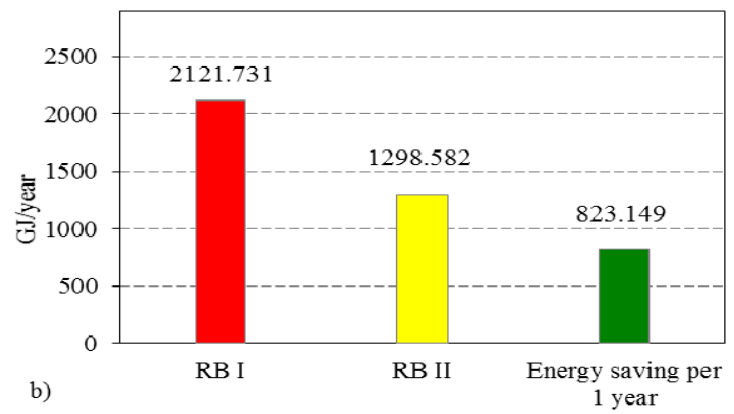

(b)

Figure 2. (a) Thermal energy consumption of the RB before and after the application of polystyrene insulation; (b) thermal energy saving of the RB before and after the application of polystyrene insulation and the exchange of windows.

Apart from energy savings, a suitable source for production of heat and its transport to the residential building is important as well. In this case, the heat is delivered from a paper processing plant, made by burning waste wood chips. The supplied heat is from a renewable source, the transport of heat takes place via a hot-water pipe from the plant to the RB. Electric energy consumption was not part of this work, as it remained at the same level as before the application of insulation of the residential building and the material and construction plan for the work had no influence on this consumption.

\subsection{Life Cycle Assessment Methodology}

The simple LCA study for the RB before and after the application of polystyrene insulation and the exchange of windows was made in accordance with the uniform LCA methodology [21,22] in the usage phase of the building. The inventory analysis data (Table 2) contains the main energy flow (heat energy consumption, Figure $2 b$ ) and main material flows for the RB, external walls before the application of insulation, insulation of external walls using a polystyrene layer, material structure of the roof structure before and after insulation, and the exchange of original wooden windows after the end of their life cycle for PVC windows with similar parameters. Apart from the system boundaries, the preparation and execution of work (including waste), similarly to handling of the RB construction materials as waste, are at the end of their life cycle.

For the life cycle impact assessment (LCIA), the SimaPro database software tool was used. To lower the uncertainty of the LCIA of the RB before and after the application of polystyrene insulation, the Ecoinvent in 3.1 databases [23] and two evaluation methods were used that evaluate-using 
different selected methods-the construction materials used, impact of such type of consumption and heating energy saving of the RB to environment at endpoints.

The evaluation method ReCiPe Endpoint (H) V1.11/Europe ReCiPe H/A has three endpoints: damage to human health, ecosystem quality, and damage to resource [24,25]. The evaluation method IMPACT 2002+ V2.12/Single score is a combination of four impact categories (endpoints): human health, ecosystem quality, resources and climate change [26,27]. The basic unit of overall environmental impacts under both evaluation methods is $\mathrm{Pt}$ (point-standard eco-indicator normalized unit). In LCIA, for the method IMPACT 2002+, 15 different impact categories (midpoints), were analyzed in detail as human toxicity is split up into "carcinogens" and "non-carcinogens".

\section{Results and Discussion}

Life cycle assessment studies provide a comprehensive overview on the energy consumption of buildings $[28,29]$. To assess the effect of the thermal energy consumption of the RB and energy saving of construction materials in the phase of usage of the RB on environment, the ReCiPe method (Figure 3a,c,e) and IMPACT 2002+ method were selected (Figure 3b,d,f).

The RB was divided into structural units before the application of insulation (Ext walls I, Roof I, Windows I), and structural units after the application of insulation (Ext walls II, Roof II, Windows II), the thermal energy demand of the RB before (Energy I) and after (Energy II) the application of insulation and the exchange of windows (Figure $3 a, b)$. The modelling of the evaluation of the impact of the RB life cycle after the application of insulation (index II) also included material inputs for the application of insulation, as well as the original structure (Table 2). The results (Figure 3a,b, Table 3) clearly show the effect of material inputs on the original structure, the effect of material inputs for the application of insulation of the RB in the selected waste category in the first year of the life cycle, and the difference in thermal energy consumption.

When making provision for the total average yearly saving of thermal energy of $39 \%$ in one year and its uniform distribution between 3 structural units (Ext walls, Roof, Windows), there is an evident decrease of impact of material composition of structural units on the environment one year after the application of insulation, causing the effect of $1 / 3$ saving on thermal energy ( 1 year. Ext walls II, 1 year. Roof II, and 1 year. Windows II) (Figure 3c,d).

The original structure of $1 \mathrm{RB}$, based on its material composition (Table 2) had quite a large impact on the environment (Figure 3, Table 3). According to some of the studies conducted $[10,19,30]$ the material composition of new residential buildings should have the smallest possible impact on energy consumption and the environment in all phases of its life cycle. Therefore, to determine the environmental impacts of construction materials of the RB before and after the application of insulation, the RB is modelled and evaluated over the phase of usage for periods of one, five, 10 and 20 years, making provision for energy savings (Figure $3 \mathrm{e}, \mathrm{f}$ ).

The results of the RB life cycle assessment may be recognized may be in relation with life cycle of materials used (phase of usage of the residential building). For example, in contrast with Atmaca and Atmaca [31], the modelling was executed for the maximum of 20 years, due to the life cycle and functionality of construction materials used for insulation (mainly polystyrene) and, similarly, due to the life cycle and the thermal and technical properties of the windows. The time effect of material composition of structural units of the RB after the application of insulation and exchange of windows (1 year. RB-II, 5 years RB-II, 10 years. RB-II, and 20 years. RB-II) was allowed in such way that for all the periods of time, the calculation also includes the once-only effect of construction materials in the first year and thermal energy consumption (making provision for energy savings) is multiplied by the number of years. In such a way it is possible to make provisions for the equal distribution of the effect of all of the construction materials of the residential building on the environment over the whole life cycle (phases of usage of the residential building). 


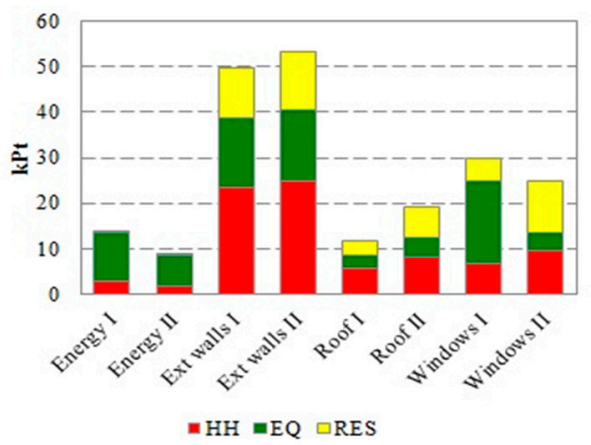

(a)

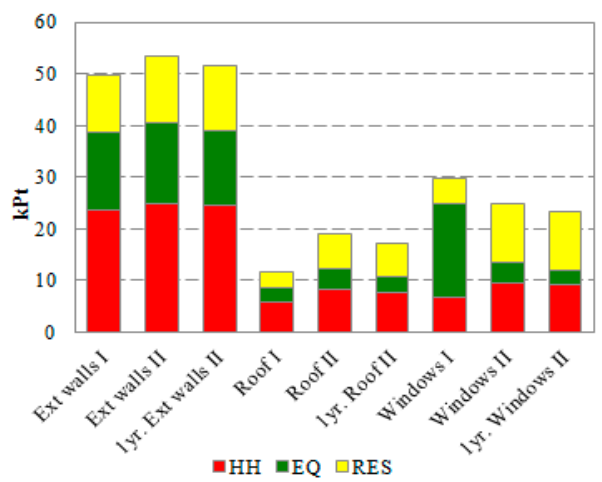

(c)

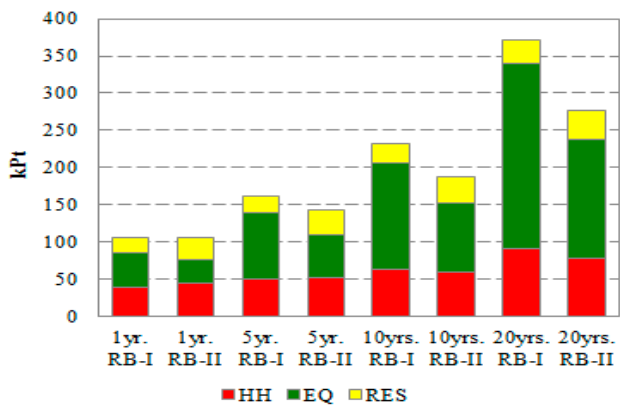

(e)

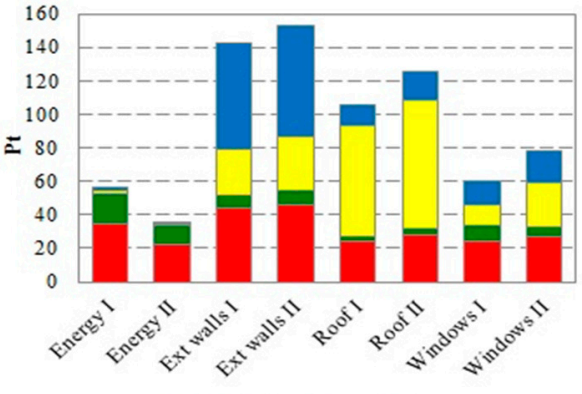

$\boxplus \mathrm{HH} \boxminus \mathrm{EQ} \square \mathrm{RES} \backsim \mathrm{CC}$

(b)

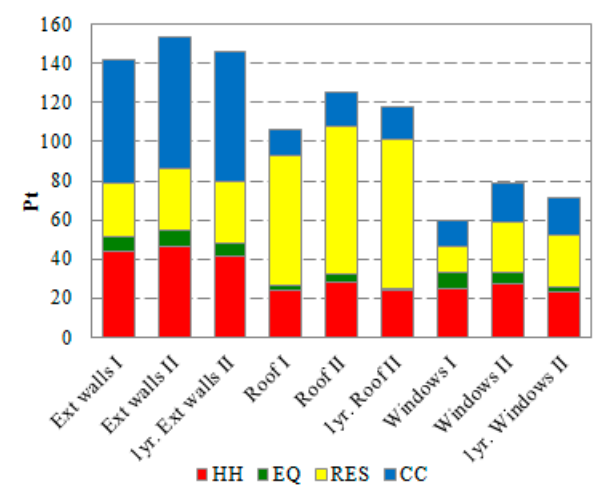

(d)

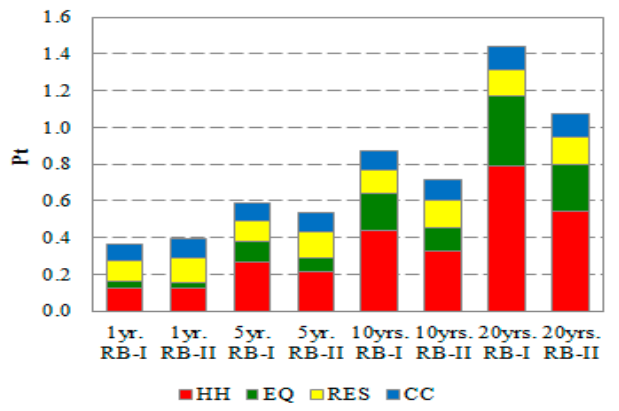

(f)

Figure 3. LCIA of the RB before (index I) and after (index II) application of polystyrene insulation and exchange of windows; (a,c,e) ReCiPe Endpoint (H)V1.11/Europe ReCiPe H/A; (b,d,f) IMPACT 2002+ V2.12/Single score; human health (HH); ecosystem quality (EQ); resources (RES); climate change (CC); modeled for one, five, 10, and 20 years; (Pt) Point-standard eco-indicator normalized unit.

The results of the LCIA of the RB show (Figure 3e,f and Figure 4, Tables 3 and 4) that the application of polystyrene insulation and exchange of windows of the RB, delivering the average yearly thermal energy saving of $39 \%$ (Figure $2 \mathrm{~b}$ ) during the long-term effect lowers the total environmental impacts of the RB, the extent of such impacts in the phase of usage of the residential building is inversely proportional to effects of the thermal energy savings over time (Tables 3 and 4). For example, $\mathrm{CO}_{2}$ emissions before insulation of $\mathrm{RB}$ were $910 \mathrm{t} \mathrm{CO}_{2} \mathrm{eq}$, and after insulation they were $1038 \mathrm{t} \mathrm{CO}_{2}$ eq (Table 3). Together with other midpoints in the first year, the insulation materials cause an increase in overall environmental damage of $1 \%$ (ReCiPe) and 7\% (IMPACT 2002+), respectively (Figure 3e,f and Figure 4 and Table 4$)$. 
Table 3. Life cycle impact assessment of the RB before (index I) and after (index II) application of polystyrene insulation and exchange of windows for the period of one, five, 10, and 20 years, IMPACT 2002+ V2.12, Characterization in midpoint.

\begin{tabular}{|c|c|c|c|c|c|c|c|c|c|}
\hline Impact Category & Unit & RB 1 Year & RB II 1 Year & RB 5 Years & RB II 5 Years & RB 10 Years & RB II 10 Years & RB 20 Years & RB II 20 Years \\
\hline Carcinogens & $\mathrm{kg} \mathrm{C}_{2} \mathrm{H}_{3} \mathrm{Cl} \mathrm{eq}$ & 30,290 & 34,591 & 34,158 & 36,844 & 38,992 & 39,660 & 48,661 & 45,291 \\
\hline Non-carcinogens & $\mathrm{kg} \mathrm{C}_{2} \mathrm{H}_{3} \mathrm{Cl}$ eq & 24,565 & 22,938 & 60,683 & 43,976 & 105,829 & 70,272 & 196,123 & 122,865 \\
\hline Respiratory inorganics & kg PM2.5 eq & 1044 & 981 & 2360 & 1748 & 4005 & 2706 & 7295 & 4622 \\
\hline Ionizing radiation & $\mathrm{kBq}^{14} \mathrm{C}$ eq & 116,197 & 116,157 & 117,421 & 116,870 & 118,952 & 117,762 & 122,012 & 119,544 \\
\hline Ozone layer depletion & $\mathrm{kg} \mathrm{CF}{ }^{11} \mathrm{C}$ eq & 0.055 & 0.714 & 0.063 & 0.718 & 0.073 & 0.724 & 0.092 & 0.735 \\
\hline Respiratory organics & $\mathrm{kg} \mathrm{C}_{2} \mathrm{H}_{4} \mathrm{eq}$ & 273.70 & 463.72 & 410.49 & 543.40 & 581.48 & 642.99 & 923.45 & 842.18 \\
\hline Aquatic ecotoxicity & t TEG water & 153,917 & 115,050 & 444,485 & 284,295 & 807,694 & 495,851 & $1,534,112$ & 918,962 \\
\hline Terrestrial ecotoxicity & t TEG soil & 43,869 & 36,299 & 148,990 & 97,528 & 280,391 & 174,064 & 543,194 & 327,137 \\
\hline Terrestrial acid/nutri & $\mathrm{kg} \mathrm{SO}_{2} \mathrm{eq}$ & 15,836 & 18,723 & 24,354 & 23,684 & 35,002 & 29,886 & 56,298 & 42,290 \\
\hline Aquatic acidification & $\mathrm{kg} \mathrm{SO} \mathrm{SO}_{2}$ & 3775 & 4299 & 5129 & 5087 & 6821 & 6073 & 10,206 & 8044 \\
\hline Aquatic eutrophication & $\mathrm{kg} \mathrm{PO}_{4}$ P-lim & 147 & 152 & 279 & 228 & 443 & 324 & 773 & 516 \\
\hline Global warming & $\mathrm{tCO}_{2} \mathrm{eq}$ & 910 & 1038 & 986 & 1082 & 1080 & 1137 & 1269 & 1247 \\
\hline Non-renewable energy & GJ primary & 16,367 & 20,527 & 17,411 & 21,135 & 18,716 & 21,895 & 21,325 & 23,414 \\
\hline Mineral extraction & GJ surplus & 68.080 & 107.413 & 73.096 & 110.335 & 79.366 & 113.987 & 91.907 & 121.292 \\
\hline
\end{tabular}




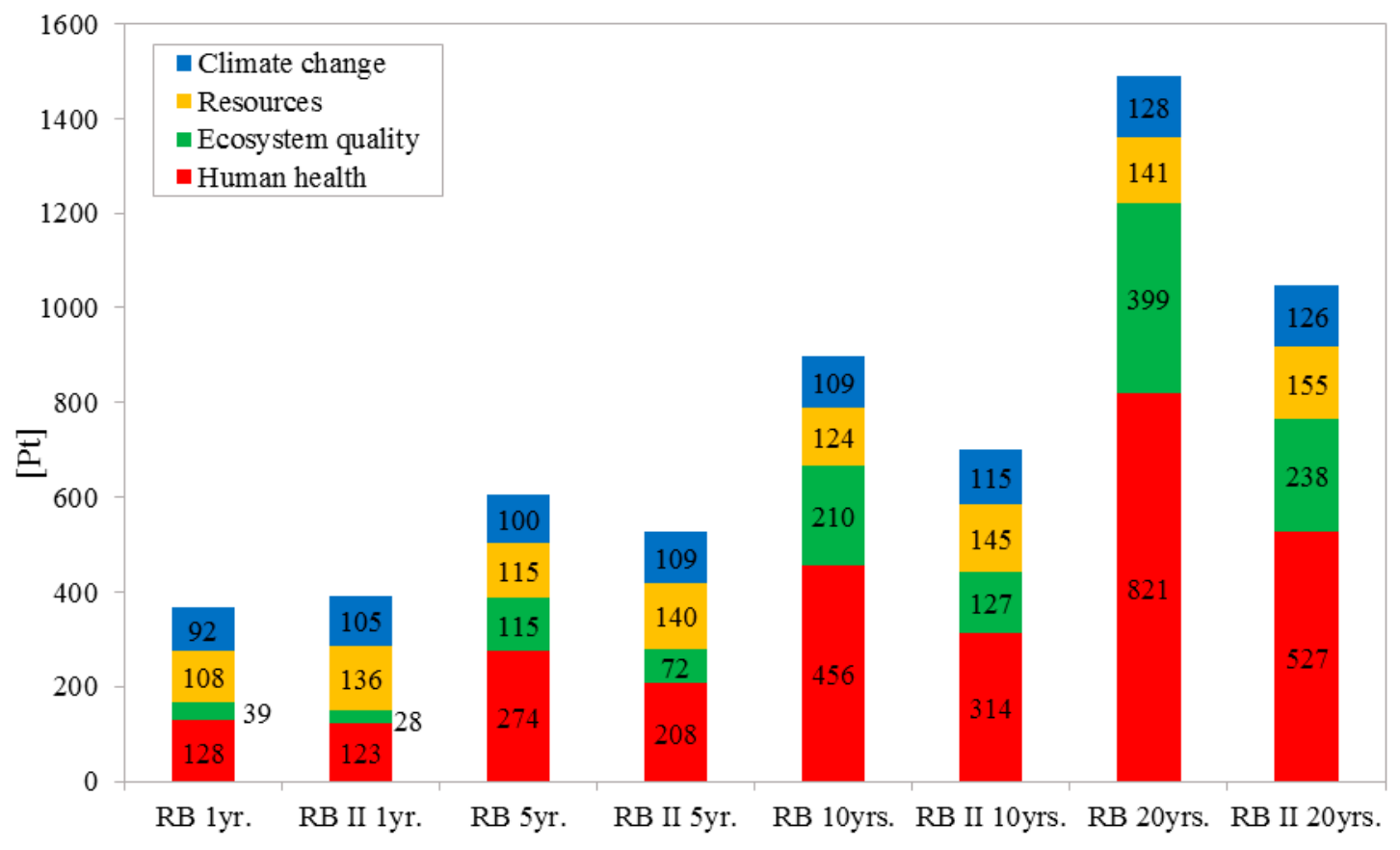

Figure 4. LCIA of the RB before (index I) and after (index II) application of polystyrene insulation and exchange of windows; IMPACT 2002+ V2.12/Single score (human health, ecosystem quality, resources, climate change); modelled for one, five, 10, and 20 years, Pt (point-standard eco-indicator normalized unit).

Table 4. The total impact of energy savings provided by the application of insulation and exchange of windows of the $1 \mathrm{RB}$ on the environment for the periods of one, five, 10, and 20 years.

\begin{tabular}{cccc}
\hline Years & TES & ReCiPe & IMPACT 2002+ \\
\hline 1 & $+39 \%$ & $-1 \%$ & $-7 \%$ \\
5 & $+39 \%$ & $+12 \%$ & $+9 \%$ \\
10 & $+39 \%$ & $+19 \%$ & $+18 \%$ \\
20 & $+39 \%$ & $+26 \%$ & $+25 \%$ \\
\hline
\end{tabular}

Since this simple study does not include the implementation of works as well as waste handling after the end of the construction material life cycle of the RB, the increment of positive impact is the highest over the period of five years (Figure $3 \mathrm{e}, \mathrm{f}$ and Figure 4). However, the environmental impact of construction materials of the RB, for the maximum theoretical functionality of construction materials (satisfactory thermal and technical parameters, i.e., for the constant average yearly thermal energy saving of $39 \%$ comparing with the state before the application of insulation) of the RB for the period of 20 years, represents a reduction of total negative impacts on the environment of $25 \%$ (ReCiPe) or $-26 \%$ (IMPACT 2002+). For example, using the method IMPACT 2002+, it is 20 years global warming $-4792 \mathrm{~kg} \mathrm{CO} 2$ eq, production of carcinogens $-2479 \mathrm{~kg} \mathrm{C}_{2} \mathrm{H}_{3} \mathrm{Cl}$ eq, acidification $-12,045 \mathrm{~kg} \mathrm{SO} 2$ eq, and aquatic eutrophication $-257 \mathrm{~kg} \mathrm{PO}_{4}$ P-lim (see Tables 3 and 4, Figure 3e,f and Figure 4). The values of increments for both LCIA methods have a relatively small and stable differences. This highlights the fact that construction materials with suitable life cycle and functionality help to lower the long-term impact of the RB on the environment by efficient energy savings, contrary to using materials with a short life cycle. The result corresponds with results of the above mentioned studies [3,14,31]. A simple change to several construction materials can cause a reduction in the environmental impact of buildings [32,33]. A number of LCA methodologies can be applied for this purpose, e.g., the simplified LCA methodology [34,35]. It has been objectively proven that the results of environmental impact of construction materials on residential houses on their energy intensity (during the use of buildings) depend on the function and usable life of the material used. 


\section{Conclusions}

Improving the energy balance of buildings is a long-term strategy in many countries of the world. In the current economic situation, the choice of thermal insulation of buildings is determined more by the momentary price of materials and labour costs than long-term environmental benefits. For this reason, simple polystyrene insulation is more often selected for the walls of buildings. The novelty of the article for Slovakia and some other Central European countries consists in using the LCA method for the objective assessment of the environmental benefits of the selected systems of wall insulation, as well as the energy savings in various time intervals of insulation functionality (up to 20 years).

The life cycle assessment methodology and SimaPro software with ReCiPe and IMPACT 2002+ assessment methods were used to quantify the total environmental impact at selected endpoints for basic structural materials of a residential building and its energy demand. Both assessment methods have confirmed the same trend of TES (thermal energy saving) due to the insulation of the walls and the roof, as well as window replacement. The IMPACT 2002+ method emphasises the negative effect of roof structure materials on the consumption of resources.

The data we have obtained through both research methods shows, that the environmental impact of polystyrene insulation of external walls, roof and exchange of windows of one residential building (RB) in the first year after insulation is higher than the reduction caused by achieving a TES of $39 \%$.

When taking a lifespan of 20 years into consideration, the impact on the life cycle of building materials is lowered by $25 \%$ (global warming: $-4792 \mathrm{~kg} \mathrm{CO}_{2}$ eq; production of carcinogens: $-2479 \mathrm{~kg}$ $\mathrm{C}_{2} \mathrm{H}_{3} \mathrm{Cl}$ eq; acidification: $-12,045 \mathrm{~kg} \mathrm{SO}$ eq.; and aquatic eutrophication: $-257 \mathrm{~kg} \mathrm{PO}_{4} \mathrm{P}-\mathrm{lim}$ ).

Acknowledgments: This work was supported by the Slovak Grant Agency VEGA under contract No. VEGA $1 / 0213 / 15$. This research was also supported by the Cultural and Educational Grant Agency of the Ministry of Education, Science, Research and Sport of the Slovak Republic project No. KEGA 035UMB-4/2015.

Author Contributions: Jozef Mitterpach prepared the initial draft of the manuscript under the guidance of Juraj Ladomerský, Emília Hroncová and Jozef Štefko. Emília Hroncová, Jozef Mitterpach and Juraj Ladomerský contributed in revising and preparing the final draft of the manuscript.

Conflicts of Interest: The authors declare no conflict of interest.

\section{References}

1. Ortiz, O.; Castells, F.; Sonnemann, G. Sustainability in the construction industry: A review of recent developments based on LCA. Constr. Build. Mater. 2009, 23, 28-39. [CrossRef]

2. Agenda 21 on Sustainable Construction. Available online: http://cic.vtt.fi/eco/cibw82/A21text.pdf (assessed on 1 December 2016).

3. Pajchrowski, G.; Noskowiak, A.; Lewandowska, A.; Strykowski, W. Materials composition or energy characteristic-What is more important in environmental life cycle of buildings? Build. Environ. 2014, 72 , 15-27. [CrossRef]

4. Khasreen, M.M.; Banfill, P.F.G.; Menzies, G.F. Life-Cycle Assessment and the Environmental Impact of Buildings: A Review. Sustainability 2009, 1, 674-701. [CrossRef]

5. Lee, S.; Tae, S.; Roh, S.; Kim, T. Green Template for Life Cycle Assessment of Buildings Based on Building Information Modeling: Focus on Embodied Environmental Impact. Sustainability 2015, 7, 16498-16512. [CrossRef]

6. Buyle, M.; Braet, J.; Audenaert, A. Life cycle assessment in the construction sector: A review. Renew. Sustain. Energy Rev. 2013, 26, 379-388. [CrossRef]

7. Asdrubali, F.; Baldassarri, C.; Fthenakis, V. Life cycle analysis in the construction sector: Guiding the optimization of conventional Italian buildings. Energy Build. 2013, 64, 73-89. [CrossRef]

8. Intergovernmental Panel On Climate Change (IPCC). Climate Change 2007: The Physical Science Basis, Contribution of Working Group I to the Fourth Assessment Report of the Intergovernmental Panel on Climate Change; Solomon, S., Qin, D., Manning, M., Chen, Z., Marquis, M., Averyt, K.B., Tignor, M., Miller, H.L., Eds.; Cambridge University Press: Cambridge, UK; New York, NY, USA, 2007. 
9. Ondova, M.; Estokova, A. Environmental impact assessment of building foundation in masonry family houses related to the total used building materials. Environ. Prog. Sustain. Energy 2016, 35, 1113-1120. [CrossRef]

10. Sartori, I.; Hestnes, A.G. Energy use in the life cycle of conventional and low-energy buildings: A review article. Energy Build. 2007, 39, 249-257. [CrossRef]

11. Scheuer, C.; Keoleian, G.A.; Reppe, P. Life cycle energy and environmental performance of a new university building: Modeling challenges and design implications. Energy Build. 2003, 35, 1049-1064. [CrossRef]

12. Guardigli, L.; Monari, F.; Bragadin, M.A. Assessing Environmental Impact of Green Buildings through LCA Methods: Acomparison between Reinforced Concrete and Wood Structures in the European Context. Procedia Eng. 2011, 21, 1199-1206. [CrossRef]

13. Chau, C.K.; Leung, T.M.; Ng, W.Y. A review on life cycle assessment, life cycle energy assessment and life cycle carbon emissions assessment on buildings. Appl. Energy 2015, 143, 395-413. [CrossRef]

14. Lewandowska, A.; Noskowiak, A.; Pajchrowski, G. Comparative life cycle assessment of passive and traditional residential buildings' use with a special focus on energy-related aspects. Energy Build. 2013, 67, 635-646. [CrossRef]

15. Abd Rashid, A.F.; Yusoff, S. A review of life cycle assessment method for building industry. Renew. Sustain. Energy Rev. 2015, 45, 244-248. [CrossRef]

16. Čuček, L.; Varbanov, P.S.; Klemeš, J.J.; Kravanja, Z. Potential of total site process integration for balancing and decreasing the key environmental footprints. Chem. Eng. Trans. 2012, 29, 61-66.

17. Oregi, X.; Hernandez, P.; Gazulla, C.; Isasa, M. Integrating Simplified and Full Life Cycle Approaches in Decision Making for Building Energy Refurbishment: Benefits and Barriers. Buildings 2015, 5, 354-380. [CrossRef]

18. Zheng, G.; Jing, Y.; Huang, H.; Zhang, X.; Gao, Y. Application of Life Cycle Assessment (LCA) and extenics theory for building energy conservation assessment. Energy 2009, 34, 1870-1879. [CrossRef]

19. Nicolae, B.; George-Vlad, B. Life cycle analysis in refurbishment of the buildings as intervention practices in energy saving. Energy Build. 2015, 86, 74-85. [CrossRef]

20. Bastos, J.; Batterman, S.A.; Freire, F. Life-cycle energy and greenhouse gas analysis of three building types in a residential area in Lisbon. Energy Build. 2014, 69, 344-353. [CrossRef]

21. ISO 14040. Environmental Management_Life Cycle Assessment_Principles and Framework. Available online: http:/ / www.iso.org/iso/catalogue_detail?csnumber=37456 (assessed on 1 December 2016).

22. ISO 14044. Environmental Managements_Life Cycle Assessments—Requirements and Guidelines. Available online: http:/ / www.iso.org/iso/catalogue_detail?csnumber=38498 (assessed on 1 December 2016).

23. Weidema, B.P.; Bauer, C.; Hischier, R.; Mutel, C.; Nemecek, T.; Reinhard, J.; Vadenbo, C.O.; Wernet, G. Data Quality Guideline for the Ecoinvent Database Version 3. Available online: http:/ /www.ecoinvent.org/ files/dataqualityguideline_ecoinvent_3_20130506.pdf (assessed on 1 December 2016).

24. Goedkoop, M.; Heijungs, R.; Huijbregts, M.; Schryver, A.; De Struijs, J.; van Zelm, R. ReCiPe 2008. Available online: http://www.leidenuniv.nl/cml/ssp/publications/recipe_characterisation.pdf (assessed on 1 December 2016).

25. Sleeswijk, A.W.; van Oers, L.F.C.M.; Guinée, J.B.; Struijs, J.; Huijbregts, M.A.J. Normalisation in product life cycle assessment: An LCA of the global and European economic systems in the year 2000. Sci. Total Environ. 2008, 390, 227-240. [CrossRef] [PubMed]

26. Frischknecht, R.; Editors, N.J.; Althaus, H.; Bauer, C.; Doka, G.; Dones, R.; Hischier, R.; Hellweg, S.; Köllner, T.; Loerincik, Y.; et al. Implementation of Life Cycle Impact Assessment Methods. Am. Midl. Nat. 2007, 150, $1-151$.

27. Jolliet, O.; Margni, M.; Charles, R.; Humbert, S.; Payet, J.; Rebitzer, G.; Robenbaum, R.K. IMPACT 2002+: A New Life Cycle Impact Assessment Methodology. Int. J. Life Cycle Assess. 2003, 8, 324-330. [CrossRef]

28. Foraboschi, P.; Mercanzin, M.; Trabucco, D. Sustainable structural design of tall buildings based on embodied energy. Energy Build. 2014, 68, 254-269. [CrossRef]

29. Trabucco, D.; Wood, A. LCA of tall buildings: Still a long way to go. J. Build. Eng. 2016, 7, 379-381. [CrossRef]

30. Jia Wen, T.; Chin Siong, H.; Noor, Z.Z. Assessment of embodied energy and global warming potential of building construction using life cycle analysis approach: Case studies of residential buildings in Iskandar Malaysia. Energy Build. 2015, 93, 295-302. [CrossRef] 
31. Atmaca, A.; Atmaca, N. Life cycle energy (LCEA) and carbon dioxide emissions (LCCO2A) assessment of two residential buildings in Gaziantep, Turkey. Energy Build. 2015, 102, 417-431. [CrossRef]

32. Fouquet, M.; Levasseur, A.; Margni, M.; Lebert, A.; Lasvaux, S.; Souyri, B.; Buhé, C.; Woloszyn, M. Methodological challenges and developments in LCA of low energy buildings: Application to biogenic carbon and global warming assessment. Build. Environ. 2015, 90, 51-59. [CrossRef]

33. Estokova, A.; Porhincak, M. Environmental analysis of two building material alternatives in structures with the aim of sustainable construction. Clean Technol. Environ. Policy 2014, 75-83. [CrossRef]

34. Zabalza Bribián, I.; Aranda Usón, A.; Scarpellini, S. Life cycle assessment in buildings: State-of-the-art and simplified LCA methodology as a complement for building certification. Build. Environ. 2009, 44, 2510-2520. [CrossRef]

35. Heinonen, J.; Säynäjoki, A.; Junnonen, J.M.; Pöyry, A.; Junnila, S. Pre-use phase LCA of a multi-story residential building: Can greenhouse gas emissions be used as a more general environmental performance indicator? Build. Environ. 2016, 95, 116-125. [CrossRef]

(C) 2016 by the authors; licensee MDPI, Basel, Switzerland. This article is an open access article distributed under the terms and conditions of the Creative Commons Attribution (CC-BY) license (http://creativecommons.org/licenses/by/4.0/). 